\title{
Coparental Relationship and Self-Efficacy of Caregivers of Children with Cerebral Palsy
}

\author{
Priscilla Bellard Mendes de Souza ${ }^{1}$ (D) https://orcid.org/0000-0003-2148-510X \\ Edson Marcos Ramos ${ }^{1}$ (D) https://orcid.org/0000-0001-5425-8531 \\ Simone Souza da Costa Silva ${ }^{1}$ (D) https://orcid.org/0000-0003-0795-2998
}

\begin{abstract}
Low parental coparenting and self-efficacy negatively impact children's development. Our study sought to describe and analyze the parental coparenting and self-efficacy of 84 caregivers of children with cerebral palsy (CP) in Brazil. We used a Sociodemographic Inventory (SDI), Gross Motor Function Classification System (GMFCS), Self-efficacy Scale and Coparenting Questionnaire (CQ). Data were subjected to descriptive statistics and Correspondence Analysis. ISD results showed the mothers as the main caregivers of children with CP, being mostly girls at level V in the GMFCS scale. Low levels of coparenting and self-efficacy were observed in young caregivers, caring for girls older than six years old. Self-efficacy was higher regarding basic and daily care such as feeding and performing personal hygiene, and lower regarding seizures and subjective aspects. No significant correlations were found between coparenting and self-efficacy. We concluded that interventions should be planned to increase parental coparenting and parental self-efficacy.
\end{abstract}

Keywords: caregivers, self-efficacy, cerebral palsy

\section{Relações Coparentais e Auto-Eficácia de Cuidadores de Crianças com Paralisia Cerebral}

\begin{abstract}
Resumo: A baixa coparentalidade e autoeficácia parental impactam negativamente no desenvolvimento dos filhos. O objetivo deste estudo foi descrever e analisar a coparentalidade e autoeficácia parental de 84 cuidadores de crianças com paralisia cerebral (PC) no Brasil. Utilizou-se: Inventário Sociodemográfico (ISD), Sistema de Classificação da Função Motora Grossa (GMFCS), Escala de Auto-eficácia, Coparenting Questionnaire (CQ). Os dados foram submetidos à estatística descritiva e à Análise de Correspondência. Os resultados do ISD mostraram que as mães são as cuidadoras principais das crianças com PC, sendo estas prioritariamente meninas, e avaliada no nível V na Escala GMFCS. Níveis baixos de coparentalidade e autoeficácia em cuidadores jovens, cuidando de meninas maiores de seis anos. A auto-eficácia foi mais elevada para cuidados básicos e diários, como alimentar e higienizar, e menores para os que envolveram convulsões, e aspectos subjetivos. Não foram encontradas correlações significativas entre coparentalidade e autoeficácia. Conclui-se que intervenções devem ser planejadas visando aumentar a coparentalidade e auto-eficácia parental.
\end{abstract}

Palavras-chave: cuidadores, autoeficácia, paralisia cerebral

\section{Relaciones Coparentales y Autoeficacia de Cuidadores de Niños con Parálisis Cerebral}

\begin{abstract}
Resumen: La baja coparentalidad y la autoeficacia parental tienen un impacto negativo en el desarrollo de los niños. El objetivo de este estudio fue describir y analizar la autoeficacia parental y la autoeficacia de 84 cuidadores de niños con parálisis cerebral (PC) en Brasil. Se utilizó: el Inventario Sociodemográfico (ISD), el Sistema de Clasificación de la Función Motora Gruesa (GMFCS), Escala de Autoeficacia, Coparenting Questionnaire(CQ). Se sometieron los datos a las estadísticas descriptivas y análisis de correspondencia. Los resultados del ISD mostraron que las madres son las principales cuidadoras de los niños con PC, que son principalmente niñas, y se evalúan en el nivel V en la escala GMFCS. Bajos niveles de coparentalidad y autoeficacia en los cuidadores jóvenes que cuidan a niñas mayores de seis años. La autoeficacia fue mayor para la atención básica y diaria, como alimentar e higienizar, y menor para aquellos que involucran convulsiones y aspectos subjetivos. No se encontraron correlaciones significativas entre coparentalidad y autoeficacia. Se concluye que las intervenciones deben planificarse para aumentar la coparentalidad y la autoeficacia parental.
\end{abstract}

Palabra clave: cuidadores, autoeficacia, parálisis cerebral

${ }^{1}$ Universidade Federal do Pará, Belém-PA, Brazil

Article derived from the main author's doctoral thesis, under the second author's supervision, defended in 2017 at the Graduate Program in Psychology of the Universidade Federal do Pará

Correspondence address: Priscilla Bellard Mendes de Souza. Universidade Federal do Pará. Rua Acesso 1 - bairro Sudam 1, Rua Anchieta, Altamira-PA, Brazil. CEP 68.317-195. E-mail: pribellard@gmail.com
The family system is a primordial context of individuals' development, emerging from the moment when husbands and wives assume parental roles (Bronfenbrenner, 2011). By becoming father and mother, inevitably, women and men face significant changes in their lives, with achievements, 
but also with challenges and problems (Alves, Arpini, \& Cúnico, 2015).

Among these challenges, the birth of a child with disabilities is an event that stands out due to specific demands according to the family structure and dynamics, and also due to personal characteristics. Each family system reacts differently, regardless of the type of disability. The common reactions include denial due to the idealization of a perfect child, and revolt, guilt and depression (Buscaglia, 1996; Franco, 2015).

Cerebral palsy (CP) stands out as the most common cause of deficiencies among the diagnoses that affect child development (Ribeiro, Vandenberghe, Prudente, Vila, $\&$ Porto, 2016). CP is part of a group of permanent disorders that affect especially the neuromotor development, which, although not progressive, compromises the posture and movement of the individuals (Rosenbaum et al., 2007).

Motor disorders associated with this pathology are often accompanied by sensory, cognitive, perceptual, communication and behavioral alterations, requiring adaptations by the family system. If these functions are not stimulated early, they can compromise the quality of life of children and their families, greatly impairing child development (Brossard-Racine et al., 2013).

Mothers usually assume the role of principal caregivers, abdicating their prior routine with the birth of their children (Ribeiro et al., 2016). Given this context, parental stress arises as one of the main risk factors for both caregivers and children, and for the entire family (Ribeiro, Sousa, Vandenbergh, \& Porto, 2014). A Colombian study sought to evaluate the reduction of parental stress in 257 participants after the application of a parenting skills training program (PSP). The data showed a reduction in the stress levels, with highest reduction among fathers when compared with mothers. These data evidence the efficacy of educational intervention programs for parents; however, they also evidence that the maternal figure is more exposed to the risk factors caused by parental stress.

Regarding parental care and its relationship with symptoms of parental stress, coparenting emerges as a new concept that can be understood as the set of tasks that two people assume when dividing childcare (Feinberg, 2003), being the coparenting relationship considered a key element on child development (Pasinato \& Mosman, 2016) even in the clinical context (Frizzo, Kreutz, Schmidt, Piccinini, $\&$ Bosa, 2005).

Among different theoretical models, the one described by Margolin (1992), organizes this concept in three general dimensions: cooperation, conflict and triangulation. The first refers to how much the couple respect, value and support each other, forming a solid foundation of emotional security for children. The conflict reflects the parental disagreement regarding child-raising issues and if it was witnessed by the children, being a risk factor for child development. Triangulation is a veiling form of child-raising conflict, in which there is a coalition between one of the caregivers and the child (or children) to "annul" the other caregiver, overstepping the boundaries of the family system. We emphasize that the last two dimensions greatly affect the quality of family relationships, which may cause episodes of parental stress (Lima, Cardoso, \& Silva, 2016).

Some studies on coparenting in atypical contexts have already been developed, demonstrating that coparenting, which arose to understand the impacts of marital divorce on the development of children (Lamela, Figueiredo, Bastos, \& Feinberg, 2016), has also been used to understand the family dynamics in specific contexts. Regarding the relationships established between the parental peers, individual efforts to handle the specific demands of each situation are observed. Among these concepts, self-efficacy has been investigated to understand the behavior of caregivers of children with disabilities regarding the competencies related to care or parental competence (Ferreira et al., 2014).

According to Bandura (1997), self-efficacy is the development of a sense of properties or abilities peculiar to the subject, which results in the domain of a specific situation that can cause a desired result. There are differences between the two components of self-efficacy, the first being an expectation of efficacy, and the second an expectation of results (Tristão, Neiva, Barnes, \& Adamson-Macedo, 2015). An expectation of results refers to the belief that a given behavior will lead to a specific result, while an expectation of efficacy is the conviction that the person itself is capable of a behavior necessary to produce a result.

An important aspect is that the understanding of the concept of self-efficacy is consistent with the concept of prospective idealization, aiming firstly at specific objectives, and the sense of efficacy has a motivational construct, relying on the personal perception of competence. Bandura (1997) defends the idea that self-efficacy beliefs determine the level of effort expended by a person in a specific activity, the time devoted to this activity and the level of resilience evidenced in the confrontation of situations when performing the task.

Thus, this concept has been transposed into the field of family relationships to refer to the degree of reliability that parents have in their parental competencies. The sense of parental self-efficacy has been suggested to be correlated to how much these parents feel capable of performing parental tasks (Gerards, Hummel, Dagnelie, de Vries, \& Kremers, 2013), and related to the improvement of their physical and mental health (A. K.C. Oliveira, Matsukura, \& Fontaine, 2017). Parental self-efficacy is connected to the feeling of control over the parental capacities of achieving a satisfactory performance in the role of father and mother, with the peculiarity of this role having a very significant affective dimension, influencing self-perception (Taylor, Lillis, LeMone, \& Lynn , 2014).

A.K.C. Oliveira et al. (2017) sought to identify studies investigating self-concept and self-efficacy in children with physical disabilities through a systematic literature review. After selecting the articles, they investigated the self-concept specifically in children with cerebral palsy. The results of this study suggested that there was no consensus on the self-concept in children with cerebral palsy, 
without sufficient evidence to conclude that this construct is lower in these children. Children with physical disabilities classified themselves as less self-effective than children with other neurodevelopmental problems.

Studies investigating relationships in families of children with disabilities are scarce in Brazil, especially those investigating both the parental and self-efficacy patterns in families of children with CP. Based on the hypothesis that caregivers of children with $\mathrm{CP}$ with low levels of coparenting also have low levels of self-efficacy in caring for their children, our study sought to describe and analyze the levels of parental coparenting and self-efficacy of caregivers of children with $\mathrm{CP}$, observing which parental behaviors show greater self-efficacy.

\section{Method}

\section{Participants}

Participated in this study 84 main caregivers of children aged between zero and 12 years diagnosed with $\mathrm{CP}$ treated in a reference center specialized in the areas of child growth and development in Belém, state of Pará, Brazil.

\section{Instruments}

Clinical record of children with $C P$. This material was provided by the Reference Center, and contained information necessary to find children with $\mathrm{CP}$ and their caregivers.

Sociodemographic Inventory (SDI). Instrument made by the Development Ecology Laboratory - LED of the Graduate program in theory and behavior studies of UFPA, with questions related to sociodemographic data (gender, age, schooling, family income, participant's religion, cause of the PC, number of children, among others).

Gross Motor Function Classification System (GMFCS). This instrument underwent cross-cultural validation for Brazil (Silva, Dias, \& Pfeifer, 2016). It evaluates the children in five levels (I, II, III, IV and V) according to the age, considering what they manage to accomplish regarding the gross motor function, especially the functions of sitting (control of the trunk) and walking. The scale is ordinal, without intend that the distances between the levels are considered equal, or that children with cerebral palsy are equally distributed among the five levels. At level I, children can move without restriction; level II, the child walks without the aid of braces and crutches, has limitations to walk outside and in the community; level III, the child manages to walk with the aid of walkers or crutches, has difficulties to walk outside and in the community; level IV, the child walks with external assistance, with limitations and needs wheelchair outside, and has limited manual activities, and level V mobility is severely limited, even with apparatus and adaptations, requiring total assistance.

Coparenting Questionnaire (CQ). This instrument has good internal consistency, with Cronbach's alpha values raging between .69 and .87 (Margolin, Gordis, \& John, 2001). Its adaptation and validation were conducted by a Portuguese study with 1,133 participants (Pedro \& Ribeiro, 2015). This instrument consisted of a scale likert of five points containing 14 items that evaluated the perception of coparenting in two aspects, positive and negative, as a function of three subscales: cooperation (items 1-5), triangulation (items 6-9) and conflict (items 10-14), with answers punctuated as follows: 1 for answer "never", 2 for "rarely", 3 for "sometimes", 4 for "usually" and 5 for "always". The positive aspect of this instrument is the reduction of respondent's social adaptability, since the procedure was made to caregivers answer not about themselves, but one about the other (Pedro \& Ribeiro, 2015).

Self-efficacy scale. The self-efficacy scale (Sofronoff \& Farbotko, 2002) was adapted to verify the self-efficacy of caregivers of children with ASD, regarding the management of specific behaviors (motor, e.g. spasms; emotional, e.g. excessive crying; and health, e.g. getting sick) of a child with $\mathrm{CP}$, with 15 items punctuated by a scale likert of six points. The answers are arranged in the scale as follows: Nothing confident ( 0 point $)$, slightly confident (1 point), a little confident ( 2 points), moderately confident ( 3 points), very confident (4 points) and completely confident ( 5 points). The higher the score, the greater the feeling of self-efficacy.

\section{Procedures}

Data collection. Caregivers and children were found and identified based on the children's clinical records. After finding the children with $\mathrm{CP}$ that fit the chosen criteria (up to twelve years old and without any type of genetic alteration and/or Autistic Spectrum Disorder-ASD), the participants were approached and interviewed in the waiting room on the days the children had appointments. When approached by the researchers, they were explained about the survey and invited to participate. The instruments were applied after the informed consent form was signed, in the following sequence: $\left(1^{\circ}\right) \mathrm{SDI} ;\left(2^{\circ}\right)$ GMFCS; $\left(3^{\circ}\right) \mathrm{CQ} ; \mathrm{e}\left(4^{\circ}\right)$ Self-Efficacy Scale. The application of the GMFCS was performed by a physiotherapist of the research team. The average duration of application of these instruments was 45 minutes.

Data analysis. The data from the SDI and GMFCS were inserted into the Statistical Package for the Social Sciences (SPSS) database, version 22.0, for descriptive statistical analysis. Coparenting and self-efficacy data were subjected to the Correspondence Analysis Technique (CA) with the aid of the Statistica application, version 6.0. CA is an exploratory statistical technique used to verify associations or similarities between qualitative variables or categorized continuous variables, and its main characteristic is the reduction of data with minimal loss (Fávero, Belfiore, Silva, $\&$ Chan, 2009). Pestana and Gageiro (2005) recommend the performance of the Chi-square test $\left(\chi^{2}\right)$ to verify the existence of dependence among the variables. The hypotheses tested are $\mathrm{H}_{0}$ : The variables are independent and $\mathrm{H}_{1}$ : The variables are dependent. 
According to Ramos, Almeida and Araújo (2008), when the simple correspondence analysis is used, the associations are propagated in a two-dimensional plane, thus, the sum of the percentage of inertia of dimensions 1 and 2 must be equal to or greater than $70 \%$ to the results be valid. Estimating the confidence coefficient $(\gamma)$ was necessary to determine the probability of a variable category to be associated with another. The associations between the categories are considered significant when the value of the confidence coefficient indicates moderately significant probabilities, that is, when or, when the value of the confidence coefficient indicates strong significant probabilities, that is, when $(\gamma) \geq 70.00 \%$.

Two groups were considered for CA based on the sample percentile theory (Bussab \& Morettin, 2011), that is, the first group with scores from 0 to $75 \%$, called the group with low coparenting and low self-efficacy, and the second group with scores from 75 to $100 \%$, the group with high levels of coparenting and self-efficacy. In the general index, the positive values of the coefficients of the variables (indices) indicate that the higher the value of the score obtained, the greater is its coparenting and self-efficacy. In all tests, $\alpha=5 \%(p \leq 0.05)$ was fixed for rejection of the null hypothesis.

\section{Ethical Considerations}

The project was submitted to the Ethics Committee of the Institute of Health Sciences of the Universidade Federal do Pará - ICS, with a favorable opinion $(473,140)$. In the informed consent form (ICF), the purposes of the study were presented, as in resolution No. 510 of April $07^{\text {th }}, 2016$ of the National Health Council/ Brazilian Ministry of Health, guaranteeing the participants of the study the confidentiality of information and the right to access the results.

\section{Results}

\section{Participants' Sociodemographic Characteristics}

Of the 84 main caregivers, $88.1 \%$ were the children's mothers, with a mean age of 32.93 years $(D P=8.5)$, predominantly from the state of Pará and married (73.80\%), living in the countryside (54.76\%). High school (64.2\%) was the predominant schooling level. Regarding the item "main occupation", $79.8 \%$ declared to be housewives. The predominant religions were Catholic (49\%) and Protestant (34\%). The child's father appeared as a secondary caregiver in $40.5 \%$ of the families, and the maternal grandmother was cited as the third main caregiver in $19 \%$.

Regarding gender, $53.6 \%$ of the children with $\mathrm{CP}$ were girls. Regarding the birth order, $83.3 \%$ were up to the third child. The mean age of the children was 6.06 years $(D P=2.9)$. Half attended school, most in early childhood education (32.1\%), and $84.52 \%$ receive some social benefit. The distribution of the GMFCS scalelevels was:LevelI (8.3\%); Level II (9.5\%); Level III (15.5\%); Level IV (20.2\%) and level V (46.4\%).
Regarding family type, the sample had $57.1 \%$ of nuclear families; $26.2 \%$ of extended families; and $16.7 \%$ of other family groups. The predominant family income was up to two minimum wages $(79.7 \%)$, followed by family income up to five minimum wages $(20.3 \%)$. When asked if there was experience of marital separation, $32.1 \%$ said yes, occurring after the diagnosis in $14.42 \%$ of the cases.

\section{Coparenting}

The coparenting was classified into two groups, and the individuals with scores between 5.05 and 12.25 ( 0 to $75 \%$ ) were considered with a low level of coparenting, and those with scores between 12.26 and 15.88 with high level of coparenting. The general mean of coparenting obtained in the sample of caregivers of children with $\mathrm{CP}$ was $10.75(D P=2.52)$, which classified 65 of caregivers with low level of coparenting.

We observed that the low level of coparenting was associated with children's gender, female, with the fact that they do not attend school, with children aged between six and 12 years, whose GMFCS evaluation indicated levels IV and V. Regarding the caregivers, the single, young, protestant, and belonging to extended families, with incomes up to two minimum wages had low coparenting. Regarding the subscales, high levels of conflict and triangulation were correlated with the low level of coparenting, as shown in Table 1.

A statistically significant correlation was observed between caregivers with a high level of coparenting and male children, aged between one and five years, whose GMFCS evaluation indicated the first three levels, and the fact that they attend school. The high coparenting was also associated with married caregivers, catholic, with family incomes between two and five minimum wages, and belonging to a nuclear family. Table 1 also shows associations between high coparenting and low levels of conflict and triangulation.

\section{Self-efficacy Data}

Table 1 shows the means of self-efficacy obtained by caregivers regarding items related to: (a) subjective aspects of children's behavior (agitation, sadness, non-interaction, irritability, excessive crying); (b) Clinical aspects of child development (getting sick, difficult eating, child difficulty to sleep at night, when the child has spasms at home and in public, when the child has seizures); and (c) routine care behaviors (going out with their child, performing personal hygiene for the child, feeding, being alone at home with their child).

Differences in the means of caregivers' self-efficacy were observed. The item "being alone at home with the child", obtained the highest mean $(M=4.01)$, which indicates that the caregivers had greater self-efficacy in this situation, followed by basic care behaviors such as performing personal care for the children $(M=4.12)$ and feeding them $(M=4.010)$. The lowest means of self-efficacy were obtained in situations involving seizure $(M=1.89)$ and spasms occurrence $(M=2.63$ and 2.69). The other means and respective behaviors to which they relate can be verified in Table 1: 
Table 1

Mean and Standard Deviation of Caregivers 'Self-Efficacy Scale

\begin{tabular}{|c|c|c|}
\hline Behaviors & Mean & Standard Deviation \\
\hline 1. When your child gets agitated when communicating & 3.20 & 1.38 \\
\hline 2. When your child gets sick & 3.24 & 1.51 \\
\hline 3. When you have to feed your child & 4.01 & 1.30 \\
\hline 4. When you have to go out alone with your child & 3.87 & 1.48 \\
\hline 3. When you have to perform personal hygiene for your child & 4.12 & 1.29 \\
\hline 6. When you have to be alone at home with your child & 4.26 & 1.23 \\
\hline 7. When your child has spasms at home & 2.65 & 1.63 \\
\hline 7. When your child has spasms in public & 2.69 & 1.75 \\
\hline 7. When your child excessively cries at home & 2.99 & 1.63 \\
\hline 7. When your child excessively cries in public & 2.92 & 1.79 \\
\hline 11. When your child gets sad & 2.80 & 1.64 \\
\hline 12. When your child suffers seizure & 1.89 & 1.67 \\
\hline 13. When your child can't sleep at night & 2.86 & 1.83 \\
\hline 14. When your child does not interact with other people & 2.71 & 1.73 \\
\hline 15. When your child is irritated & 3.11 & 1.67 \\
\hline
\end{tabular}

The caregivers' self-efficacy was divided into two groups based on the CA. Individuals with scores between 2.73 and 10.93 were considered with low level of self-efficacy, and those with scores between 10.94 and 13.67 with high level. The general mean obtained by the caregivers in the selfefficacy scale was $8.57(D P=2.80)$, which classified 63 caregivers with low self-efficacy.

Low self-efficacy was observed in caregivers of girls, who attend school, aged between six and 12 years.
Young caregivers, belonging to a nuclear family, with a family income of one to two minimum wages and catholic showed low self-efficacy.

The caregivers of boys between one and five years old that did not attend school, and older caregivers (45 to 55 years), belonging to extended families, with family income between two to five minimum wages and protestant had high levels of self-efficacy. All correlations can be observed in Table 2:

Table 2

Residues and confidence levels (in parentheses), resulting from correspondence analysis (CA)

\begin{tabular}{lccc}
\hline Variable & Category & Self-Efficacy Low & High \\
\hline Child's gender & Female & $1.34(82.03)^{*}$ & $-2.32(0.00)$ \\
& Male & $-1.44(0.00)$ & $2.50(98.74)$ \\
Child Attends School & Yes & $1.54(87.72)$ & $-2.67(0.00)$ \\
& No & $-1.54(0.00)$ & $2.67(99.25)^{*}$ \\
Caregiver's Stage of Life & Young & $1.68(90.66)^{*}$ & $-2.91(0.00)$ \\
& Middle age & $-0.19(0.00)$ & $0.33(26.11)$ \\
Religion & Older adult & $-2.67(0.00)$ & $4.63(100.00)^{*}$ \\
& Protestant & $-1.54(0.00)$ & $1.78(92.53)^{*}$ \\
Household income & Catholic & $0.85(60.39)$ & $-1.47(0.00)$ \\
& $1-2$ minimum wages & $1.46(85.44)^{*}$ & $-2.52(0.00)$ \\
Family type & $2-5$ minimum wages & $-3.00(0.00)$ & $5.20(100.00)^{*}$ \\
Child's age & & $-1.33(0.00)$ & $2.31(97.91)^{*}$ \\
& Extended & $1.15(75.18)^{*}$ & $-2.00(0.00)$ \\
\end{tabular}

Note.**Moderately significant probabilities as. * Strongly significant odds, as. 


\section{Correlation between Self-Efficacy and Coparenting}

No statistically significant correlation was observed between the general self-efficacy and coparenting scores $(p=0.131)$. Thus, we focused on the correlation between self-efficacy of caregivers and the factors of coparenting.
We observed that low level of self-efficacy was associated with high level of conflict and low level of cooperation. High level of self-efficacy was statistically associated with high triangulation, low conflict and high cooperation, as observed in Table 3:

Table 3

Residues and Confidence Levels - resulting from the Correspondence Analysis Technique between the Coparenting Factors and Caregivers'Self-efficacy

\begin{tabular}{lcccccccc}
\hline \multirow{2}{*}{ Variable } & \multirow{2}{*}{ Category } & \multicolumn{2}{c}{ Cooperation } & \multicolumn{2}{c}{ Triangulation } & \multicolumn{2}{c}{ Conflict } \\
& & Low & High & Low & High & Low & High \\
\multirow{2}{*}{ Self-Efficacy } & Low & $2.39(98.33)^{*}$ & $-4.15(0.00)$ & $0.64(47.79)$ & $-1.11(0.00)$ & $-0.63(0.00)$ & $1.09(72.48)^{*}$ \\
& High & $-4.15(0.00)$ & $7.18(100.00)^{*}$ & $-1.04(0.00)$ & $1.81(92.90)^{*}$ & $1.09(72.48)^{*}$ & $-1.89(0.00)$ \\
\hline
\end{tabular}

Note. ${ }^{*}$ Moderately significant probabilities as . ${ }^{*}$ Strongly significant odds, as .

\section{Discussion}

Caregivers of children with disabilities organize their lives according to the caregiving, which can be permanent, considering a child with CP (Franco, 2015). Participants' sociodemographic data showed the mothers as the main caregivers, abdicating, especially, the professional activities they performed before the diagnosis, reinforcing results of similar studies (Tabaquim, Vieira, Razera, \& Ciasca, 2015).

The GMFCS Scale assessment data showed that children had serious motor impairment, with functional limitations, requiring full-time care, which would possibly require greater physical, emotional and cognitive resources from these caregivers for an indeterminate time, which can be overwhelming and compromise their quality of life.

Considering that coparenting should be experienced at least by two people (Carvalho, Barham, Souza, Böing, Crepaldi, \& Vieira, 2018), the father appeared as a secondary coparenting figure in our study, with the maternal grandmother being cited as the third caregiver (19\%). These data are not much different from previous studies on coparenting in families of children with atypical development (CerqueiraSilva \& Dessen, 2018; Sifuentes \& Bosa, 2010), in which the father was also referenced in this role, especially because most of these studies were developed with nuclear families.

Although they represent different aspects within families and among the caregivers, most of primary caregivers of children with $\mathrm{CP}$ in our study had low levels of both perception of coparenting and self-efficacy, or were negative, and significantly correlated with their personal characteristics and contexts, corroborating the bioecological conception of human development (Bronfenbrenner, 2011).

Among the caregivers' personal characteristics that most influenced their low coparenting and belief in parental self-efficacy were the fact that they were single, belonging to extended families, and being protestant, as well as caring for girls over six years old, corroborating previous studies (Augustin \& Frizzo, 2015; Lamela, Nunes-Costa, \& Figueiredo, 2010; Tabaquim et al., 2015). In a recent study
(France, Cardoso, Moraes, \& Silva, 2015) with 12 families of children with $\mathrm{CP}$, the authors found that the secondary caregivers, the fathers, showed high levels of cooperation and triangulation, and the primary caregivers, the mothers, showed high levels of coparenting conflict.

In our study, the initial hypothesis was a low perception of self-efficacy in caregivers with low coparenting, which was confirmed by the strong correlation between low cooperation and high coparenting conflict, and the negative perception of self-efficacy of caregivers. For Bandura (1997), emotional and physiological states are among the aspects that directly influence people's perception of self-efficacy. Therefore, the low coparenting perceived by caregivers may have influenced the negative perception of parental self-efficacy, since they are more likely to be the only caregiver, which physically and emotionally overwhelms them.

The aspects, of which the caregivers had a positive perception of their self-efficacy, are related to the daily routine of children such as feeding them, bathing them and going out with them. Tal positive perception in the execution of these tasks can be justified by the time exclusively dedicated by caregivers in the performance of these activities, constituting what Bandura exposes (1997) about experiences of a personal domain of performance. On the other hand, believing to be successful in the execution of a given task, which the author calls "an expectation of efficacy", is an important regulator of cognitive and emotional states.

The perception of parental self-efficacy was negative regarding subjective aspects such as "seeing their children sad", and clinical aspects such as "witnessing seizures and spasticity", complications resulting from CP (Oliveira, Valarelli, Caldas, Nascimento, \& Dantas, 2015; Santos, 2014).The need for parental emotional control is evident in both cases. However, the clinical demands imply that caregivers understand minimally about how to deal with these situations, which is called "Health Literacy" in the literature (Quemelo, Milani, Bento, Vieira, \& Zaia, 2017). In this particular aspect, we point the caregivers' low schooling level as being possibly associated with limited 
understanding about their children's developmental alteration and its probable causes and consequences.

Regarding the feeling of self-efficacy at children's sadness, the data reinforce results published in a previous study (Ferreira et al., 2014) that showed fathers and mothers feeling less self-effective when dealing with such situations, which is called "empathic responsiveness" in the literature (Ferreira et al., 2014; Guillamón et al., 2013). Regarding to the analysis of the occurrence of this fact in the caregivers of our study, we focus on the children's motor characteristics recorded, whose predominant evaluation in level V of the GMFCS scale implies serious limitations, among which the communication difficulties with their caregivers stand out.

In general, the data did not show a statistically significant correlation between the general indices of coparenting and self-efficacy; however, significant associations were found between the coparenting dimensions (cooperation, conflict and triangulation) and caregivers' self-efficacy.

The data showed caregivers with low levels of coparenting and self-efficacy. Nonetheless, the more detailed analysis of the answers to the instruments revealed the children's behaviors, at which the parents felt more or less effective. The data showed, for example, low self-efficacy at children's emotional demands, which may set potential parental stress factors. Thus, this information is important because they indicate aspects to be considered in an intervention process. We believe that actions with families can contribute to the positive construction of coparenting and perception of parental self-efficacy in caregivers of children with CP.

The participants' socio-demographic profile, with a specific sample of low income and schooling, besides the fact that the study was performed in only one child care center, may be limitations of our study. Studies interviewing a larger number of participants and performed in different specialized centers can broaden this investigation. Finally, we expect these data to benefit the attention and organization of care services directed to children and their caregivers.

\section{References}

Augustin, D., \& Frizzo, G. B. (2015). A coparentalidade ao longo do desenvolvimento dos filhos: Estabilidade e mudança no $1^{\circ}$ e $6^{\circ}$ ano de vida [Coparenting along child development: Stability and change from 1st to 6th year of child's life]. Interação em Psicologia, 19(1), 13-24. doi:10.5380/psi.v19i1.29239

Alves, A. P., Arpini, D. M., \& Cúnico, S. D. (2015). Guarda compartilhada: Perspectivas e desafios diante da responsabilidade parental [Shared guardianship: Perspectives and challenges regarding parental responsibility]. Estudos e Pesquisas em Psicologia, 15(3), 916-935. Retrieved from http://pepsic.bvsalud.org/scielo.php?script $=$ sci_ arttext\&pid=S1808-42812015000300008
Bandura, A. (1997). Self-efficacy: The exercise of control. New York, NY: W. H. Freeman.

Bronfenbrenner, U. (2011). Bioecologia do desenvolvimento humano: Tornando os seres humanos mais humanos [Making human beings human: Bioecological perspectives on human development (A. CarvalhoBarreto, Trad.). Porto Alegre, RS: Artmed.

Brossard-Racine,M.,Waknin,J.,Shikako-Thomas,K.,Shevell, M., Poulin, C., Lach, L., ... Majnemer, A. (2013). Behavioral difficulties in adolescents with cerebral palsy. Journal Child Neurology, 28(1), 27-33. doi: $10.1177 / 0883073812461942$

Buscaglia, L. F. (1996). Os deficientes e seus pais: Um desafio ao aconselhamento [The disabled and their parents: A counseling challenge] (R. Mendes, Trad.). Rio de Janeiro, RJ: Record.

Bussab, W. O., \& Morettin, P. A. (2011). Estatística básica (6a ed.). São Paulo, SP: Saraiva.

Carvalho, T. R., Barha, E. J., Souza, C. D., Böing, E., Crepaldi, M. A., \& Vieira, M. L. (2018). Cross-cultural adaptation of an instrument to assess coparenting: Coparenting Relationship Scale. Psico-USF, 23(2), 215-227. doi: 10.1590/1413-82712018230203

Cerqueira-Silva, S. C., \& Dessen, M. A. (2018). Programas de educação familiar para famílias de crianças com deficiência: Uma proposta promissora. Contextos Clínicos, 11(1), 59-71. doi:10.4013/ctc.2018.111.05

Fávero, L.P.L., Belfiore, P.P., Silva, F.L., \& Chan, B. L. (2009). Análise dos dados: Modelagem multivariada para tomada de decisões. Rio de Janeiro, RJ: Elsevier.

Feinberg, M. E. (2003). The internal structure and ecological context of coparenting: A framework for research and intervention.Parenting: ScienceandPractice, 3(2),95-131. doi:10.1207/S15327922PAR0302_01

Ferreira, B., Monteiro, L., Fernandes, C., Cardoso, J., Veríssimo, M., \& Santos, A. J. (2014). Percepção de competência parental: Exploração de domínio geral de competência e domínios específicos de auto-eficácia, numa amostra de pais e mães portuguesas. Análise Psicológica, 32(2), 145-156. doi:10.14417/ap.854

Franco, V. (2015). Introdução à intervenção precoce no desenvolvimento da criança: Com a família, na comunidade, em equipe. Porto, Portugal: Aloendro.

França, I. L., Cardoso, V. S., Moraes, C. S., \& Silva, S. S. C. (2015). Famílias de crianças com paralisia cerebral: Perfil e rotina. In R. D. L.Albuquerque \& S.E. R. Brasil (Orgs.), Inclusão de pessoas com deficiência no contexto amazônico (Vol. 2, pp. 151-165). Belém, PA: L \& A Editora. 
Frizzo, G. B., Kreutz, C., Schmidt, C., Piccinini, C. A., \& Bosa, C. A. (2005). O conceito de coparentalidade e suas implicações para pesquisa e a clínica [The concept of co-parenting: Implication for research and clinical practice]. Revista Brasileira de Crescimento e Desenvolvimento Humano, 15(3), 84-94. Retrieved from http://pepsic.bvsalud.org/scielo.php?script=sci arttext\&pid $=$ S0104-12822005000300010

Gerards, S. M. P. L., Hummel, K., Dagnelie, P., de Vries, N. K., \& Kremers , S. P. J. (2013). Parental self-efficacy in childhood overweight: Validation of the Lifestyle Behavior Checklist in the Netherlands. International Journal of Behavioral Nutrition and Physical Activity, 10, 7. doi:10.1186/1479-5868-10-7

Guillamón, N., Nieto, R., Pousada, M., Redolar, D., Muñoz, E., Hernández, E., ... Gómez-Zúñiga, B. (2013). Quality of life and mental health among parents of children with cerebral palsy: The influence of self-efficacy and coping strategies. Journal of Clinical Nursing, 22(11-12), 1579-1590. doi:10.1111/jocn.12124

Lamela, D., Figueiredo, B., Bastos, A., \& Feinberg, M. (2016). Typologies of post-divorce coparenting and parental wellbeing, parenting quality and children's psychological adjustment. Child Psychiatry and Human Development, 47(5), 716-728. doi:10.1007/s10578-015-0604-5

Lamela, D., Nunes-Costa, R., \& Figueiredo, B. (2010). Modelos teóricos das relações coparentais: Revisão crítica [Theoretical models of coparenting relations: Critical review]. Psicologia em Estudo, 15(1), 205-216. doi:10.1590/S1413-73722010000100022

Lima, M. B. S., Cardoso, V. S., \& Silva, S. S. C. (2016). Estresse Parental e Apoio Social de Cuidadores de Crianças com Paralisia Cerebral. Paidéia (Ribeirão Preto), 26(64), 207214. https://dx.doi.org/10.1590/1982-43272664201608

Margolin, G. (1992). Marital conflict is not marital conflict. In R. D. Peters \& R. J. McMahon (Eds.), Social learning and systems approaches to marriage and the family (pp. 193-216). New York, NY: Brunner/Mazel.

Margolin, G., Gordis, E. B., \& John, R. S. (2001). Coparenting: A link between marital conflict and parenting in twoparent families. Journal of Family Psychology, 15(1), 3-21. doi:10.1037/0893-3200.15.1.3

Oliveira, A. K. C., Matsukura, T. S., \& Fontaine, A. M. G. V. (2017). Autoconceito e autoeficácia em crianças com deficiência física: Revisão sistemática da literatura [Self-concept and self-efficacy in children with physical disabilities: Systematic review of literature]. Revista Brasileira de Educação Especial, 23(1), 145-160. doi:10.1590/s1413-65382317000100011

Oliveira, L., Valarelli, L. P., Caldas, C. A. C. T., Nascimento, W. V., \& Dantas, R. O. (2015). Therapeutic intervention and family acceptance in a case of child with cerebral palsy. Revista CEFAC, 17(1), 286-290. doi:10.1590/1982-021620157714
Pasinato, L. \& Mosmann, C. (2016). Transição para a parentalidade e a coparentalidade: casais que os lhos ingressaram na escola ao término da licença-maternidade. Avances en Psicología Latinoamericana, 34(1), 129-142.

Pestana, M. H., \& Gageiro, J. N. (2005). Análise de dados para ciências sociais: A complementaridade do SPSS (4a ed.). Lisboa, Portugal: Sílabo.

Pedro, M. F., \& Ribeiro, M. T. (2015). Adaptação portuguesa do questionário de coparentalidade: Análise fatorial confirmatória e estudos de validade e fiabilidade [Portuguese adaptation of the coparenting questionnaire: Confirmatory factor analysis, validity and reliability]. Psicologia: Reflexão e Crítica, 28(1), 116-125. doi:10.1590/1678-7153.201528113

Quemelo, P. R. V., Milani, D., Bento, V. F., Vieira, E. R., \& Zaia, J. E. (2017). Literacia em saúde: Tradução e validação de instrumento para pesquisa em promoção da saúde no Brasil [Health literacy: Translation and validation of a research instrument on health promotion in Brazill. Cadernos de Saúde Pública, 33(2), e00179715. doi:10.1590/0102-311x00179715

Ramos, E. M. L. S., Almeida, S. S., \& Araújo, A. R. (2008). Segurança pública: Uma abordagem estatística e computacional. Belém, PA: EDUFPA.

Ribeiro, M. F. M., Sousa, A. L. L., Vandenberghe, L., \& Porto, C. C. (2014). Parental stress in mothers of children and adolescents with cerebral palsy. Revista Latino-Americana de Enfermagem, 22(3), 440-447. doi:10.1590/0104-1169.3409.2435

Ribeiro, M. F. M., Vandenberghe, L., Prudente, C. O. M., Vila, V. S. C., \& Porto, C. C. (2016). Cerebral palsy: How the child's age and severity of impairment affect the mother's stress and coping strategies. Ciência \& Saúde Coletiva, 21(10), 3203-3212. doi:10.1590/1413812320152110.17352016

Rosenbaum, P., Paneth, N., Leviton, A., Goldstein, M., Bax, M., Damiano, D., ... Jacobsson B. (2007). A report: The definition and classification of cerebral palsy. Developmental Medicine \& Child Neurology, 49(s109), 8-14. doi:10.1111/j.1469-8749.2007.tb12610.x

Santos, A. F. (2014). Paralisia cerebral: Uma revisão da literatura [Cerebral palsy: A literature review]. Revista Unimontes Cientifica, 16(2), 67-82. Retrieved from http://www.ruc. unimontes.br/index.php/unicientifica/article/view/272

Sifuentes, M., \& Bosa, C. A. (2010). Criando pré-escolares com autismo: Características e desafios da coparentalidade [Raising autistic preschoolers: Characteristics and challenges of coparenting]. Psicologia em Estudo, 15(3), 477-485. doi:10.1590/S1413-73722010000300005

Silva, D. B. R., Dias, L. B., \& Pfeifer, L. I. (2016). Reliability of the Gross Motor Function Classification System Expanded and Revised (GMFCS E \& R) among students and health professionals in Brazil. Fisioterapia e Pesquisa, 23(2), 142-147. doi:10.1590/1809-2950/14396823022016 
Sofronoff, K., \& Farbotko, M. (2002). The effectiveness of parent management training to increase self-efficacy in parents of children with Asperger syndrome. Autism, 6(3), 271-286. doi:10.1177/1362361302006003005

Tabaquim, M. L. M., Vieira, R. G. S., Razera, A. P. R., \& Ciasca, S. M. (2015). Auto-eficácia de cuidadores de crianças com o transtorno do espectro autista [Self-efficacy of caregivers of children with autism spectrum disorder]. Revista Psicopedagogia, 32(99), 285-292. Retrieved from http://pepsic.bvsalud.org/scielo.php?script=sci arttext\&pid=S0103-84862015000300002

Taylor, C. R., Lillis, C., LeMone, P., \& Lynn, P. (2014). Fundamentos da enfermagem: $A$ arte e a ciência do cuidado de enfermagem (A. M. V. Thorell \& R. M. Garcez, Trans., 7th ed.). Porto Alegre, RS: Artmed.

Tristão, R. M., Neiva, E. R., Barnes, C. R, \& Adamson-Macedo, E. (2015). Validação da escala percepção de autoeficácia da parentalidade materna em amostra brasileira. Journal of Human Growth and Development, 25(3), 277-286. https://dx.doi.org/10.7322/jhgd.96759

Priscilla Bellard Mendes de Souza is a Professor of the Faculdade de Psicologia of the Universidade Federal do Pará, Belém-PA, Brazil.

Edson Marcos Ramos is a Professor of the Faculdade de Estatística da Universidade Federal do Pará, Belém-PA, Brazil.

Simone Souza da Costa Silva is a Professor of the Universidade Federal do Pará, Belém-PA, Brazil.

Authors' Contribution:

All authors made substantial contributions to the conception and design of this study, to data analysis and interpretation, and to the manuscript revision and approval of the final version. All the authors assume public responsability for content of the manuscript.

Received: Jul. 20, 2017

1st Revision: Nov. 05, 2017

2nd Revision: Jan. 25, 2018

Approved: Feb. 12, 2018

How to cite this article:

De Souza, P. B. M., Ramos, E. M., \& Silva, S. S. C. (2019). Coparental relationships and self-efficacy of caregivers of children with cerebral palsy. Paidéia (Ribeirão Preto), 29, e2938. doi: http://dx.doi.org/10.1590/1982-4327e2938 